\title{
Liver cell dysplasia and risk of hepatocellular carcinoma in cirrhosis: a preliminary report
}

Mauro Borzio, Savino Bruno, Massimo Roncalli, Guido Colloredo Mels, Giorgio Ramella, Franco Borzio, Gioacchino Leandro, Mauro Podda

First Department of Medicine and Department of Pathology,

Fatebenefratelli Hospital, 20129 Milan, Italy

Mauro Borzio, MD, assistan

Franco Borzio, MD, assistant

First Department of

Medicine and Second

Department of Pathology,

School of Medicine

$S$ Paolo, University of

Milan, Milan

Savino Bruno, MD, assistan

Massimo Roncalli, MD,

assistant

Mauro Podda, MD, professor

of medicine

Department of Medicine, Bolognini Hospital,

Seriate, Italy

Guido Colloredo Mels, MD, assistant

\section{First Department of}

Medicine, Predabissi

Hospital, Melegnano, Italy

Giorgio Ramella, MD,

assistant

Department of Medicine, Castellana Grotte Hospital, Bari, Italy

Gioacchino Leandro, MD, assistant

Correspondence to:

Dr M Borzio, First

Department of Medicine.

BMF 1991;302:1312
Preneoplastic-dysplastic lesions are well recognised in many models of experimental hepatic carcinogenesis.' In humans the premalignant nature of liver cell dysplasia is still controversial. Only prospective studies can establish whether patients with liver cell dysplasia have an increased risk of developing hepatocellular carcinoma. In 1984 we started a long term prospective study of a cohort of patients with cirrhosis of the liver. We report here the results of an interim analysis.

\section{Patients, methods, and results}

From January 1984 to March 1989 we enrolled into the study 274 consecutive patients from whom histological specimens showing cirrhosis of the liver had been obtained. Liver biopsy (done during laparoscopy in 219 cases) had been performed in the three months before enrolment. The main exclusion criteria were evidence of malignant lesions of the liver (either ultrasonic evidence or a high serum $\alpha$ fetoprotein concentration) and age over 75 . Follow up included ultrasonography and assays of $\alpha$ fetoprotein concentration every six months. Liver cell dysplasia was diagnosed if the morphological criteria proposed by Anthony et al were present ${ }^{2}$ : groups of hepatocytes in all or several nodules with cellular enlargement, nuclear pleomorphism and hyperchromatism, multinucleation, and normal ratio of nucleus to cytoplasm with nuclear diameter $\geqslant 11 \mu \mathrm{m}$; these findings were always confirmed by two independent observers (ES, MR). Hepatocellular carcinoma detected by ultrasound examination was always confirmed by cytological or histological examination, or both. Markers of hepatitis B virus and $\alpha$ fetoprotein concentration were assayed with commercial kits.

Data were expressed as means (SD). The likelihood ratio $\chi^{2}$ test, analysis of variance, life table analysis, and the Cox regression model were used. Confidence intervals were also determined.

At enrolment 63 patients had liver cell dysplasia. There were no differences between them and the other patients in sex distribution, mean age, or Child score. The prevalence of liver cell dysplasia was significantly higher $(p<0.05)$ in patients with cirrhosis who were positive for hepatitis B surface antigen (24/63) than in those who were negative for the antigen (21/211). The mean duration of follow up was 32 (19) months. Twenty two patients (seven with and 15 without liver cell dysplasia) died during follow up: none of them had developed hepatocellular carcinoma.

Hepatocellular carcinoma was diagnosed in 20 patients (table). When the tumours were first detected their maximum diameters ranged from 1.8 to $4.6 \mathrm{~cm}$ (mean $3.2(0 \cdot 8) \mathrm{cm}$ ) and serum $\alpha$ fetoprotein concentration was $>400 \mu \mathrm{g} / \mathrm{l}$ in only six cases. Patients who developed hepatocellular carcinoma were more likely to have had liver cell dysplasia or been positive for hepatitis B surface antigen at entry to the study; there was no difference in age or Child score at entry to the study between those who did and did not develop hepatocellular carcinoma. The relative risk $(95 \%$ confidence interval) of developing hepatocellular carcinoma was $6.2(2.4$ to 16.4$)$ for patients with dysplasia and $4.2(1.6$ to 10.8$)$ for patients positive for hepatitis B surface antigen. By life table analysis the cumulative probability of developing hepatocellular carcinoma was significantly higher $(p<0.01)$ for patients with dysplasia than for those without. In the Cox analysis liver cell dysplasia $(p<0.01)$, age over 60 $(\mathrm{p}<0.01)$, and being positive for hepatitis B surface antigen $(p=0.056)$ were independent risk factors.

Characteristics of patients with cirrhoris who did and did not develop hepatocellular carcinoma (figures are numbers (percentages) of patients)

\begin{tabular}{|c|c|c|}
\hline & \multicolumn{2}{|c|}{$\begin{array}{c}\text { Developed hepatocellula } \\
\text { carcinoma }\end{array}$} \\
\hline & $\begin{array}{c}\text { Yes } \\
(n=20)\end{array}$ & $\begin{array}{c}\text { No } \\
(\mathrm{n}=254)\end{array}$ \\
\hline $\begin{array}{l}\text { Male } \\
\text { Positive for hepatitis B surface antigen } \\
\text { With liver cell dysplasia at entry to study }\end{array}$ & $\begin{array}{l}13(65) \\
9(45)^{\star} \\
13(65)^{\star}\end{array}$ & $\begin{array}{r}150(59) \\
36(14) \\
50(20)\end{array}$ \\
\hline
\end{tabular}

${ }^{\star} \mathrm{p}<0.05$ Compared with patients who did not develop hepatocellular carcinoma.

\section{Comment}

Our patients, from several centres, were representative of the general Italian population with cirrhosis in terms of the prevalence of men, aetiology of the disease, and prevalence of liver cell dysplasia. ${ }^{34}$ Our preliminary data indicate that histologically evident liver cell dysplasia in patients with cirrhosis is independently associated with an increased risk of hepatocellular carcinoma. We also found age over 60 and being positive for hepatitis $B$ surface antigen to be independent risk factors. The frequent association of hepatocellular carcinoma with chronic hepatitis B virus infection confirms the importance of this infection in hepatic carcinogenesis in highly endemic areas.

Our preliminary results indicate that liver cell dysplasia should be looked for in patients with cirrhosis to identify those requiring careful follow up to enable early detection of hepatocellular carcinoma.

This work was presented in part at the 25th meeting of the European Association for the Study of the Liver in Budapest, 3-6 October 1990.

1 Farber E. Hyperplastic areas, hyperplastic nodules and hyperbasophilic areas as putative precursor lesions. Cancer Res 1976;36:2532-3.

2 Anthony PP, Vogel CL, Barker LF. Liver cell dysplasia: a premalignant condition. I Clin Pathol 1973;26:217-23.

3 Roncalli $M$, Borzio M, De Biagi G, et al. Liver cell dysplasia in cirrhosis: a serologic, and immunohistochemical study. Cancer 1986;57:1515-21.

4 Villa E, Baldini GM, Pasquinelli C, et al. Risk factors for hepatocellular carcinoma in Italy. Cancer 1988;62:611-5.

5 Pagliaro L, Simonetti RG, Craxi A, et al. Alcohol and HBV infection as risk factors for hepatocellular carcinoma in Italy: a multicentric, controlled study. Hepatogastroenterology 1983;30:48-50.

(Accepted 1 March 1991) 